\title{
Clinical Characteristics and Prognosis of Anti-Alpha- Amino-3-Hydroxy-5- Methyl-4-Isoxazolepropionic Acid Receptor Encephalitis
}

\author{
Zhe Zhang \\ Peking Union Medical College Hospital, Chinese Academy of Medical Sciences \\ Siyuan Fan \\ Peking Union Medical College Hospital, Chinese Academy of Medical Sciences \\ Haitao Ren \\ Peking Union Medical College Hospital, Chinese Academy of Medical Sciences \\ Lixin Zhou ( $\nabla$ zhoulixin_pumch@163.com) \\ Peking Union Medical College Hospital, Chinese Academy of Medical Sciences \\ Hongzhi Guan \\ Peking Union Medical College Hospital, Chinese Academy of Medical Sciences
}

\section{Research Article}

Keywords: antibody-mediated encephalitis, autoimmune encephalitis, alpha-amino-3-hydroxy-5-methyl-4-isoxazolepropionic acid receptor, AMPAR, limbic encephalitis, paraneoplastic encephalitis

Posted Date: October 18th, 2021

DOI: https://doi.org/10.21203/rs.3.rs-944492/v1

License: @ (i) This work is licensed under a Creative Commons Attribution 4.0 International License. Read Full License

Version of Record: A version of this preprint was published at BMC Neurology on December 1st, 2021. See the published version at https://doi.org/10.1186/s12883-021-02520-1. 


\section{Abstract \\ Background}

Encephalitis associated with antibodies against alpha-amino-3-hydroxy-5-methyl-4-isoxazolepropionic acid receptor (AMPAR) is an extremely rare type of antibody-mediated encephalitis. This research aims to investigate the clinical characteristics and prognosis of anti-AMPAR encephalitis.

\section{Methods}

This retrospective study enrolled nine patients with anti-AMPAR encephalitis. Demographic information, clinical manifestations, laboratory and radiological findings, treatment and response were collected and analyzed. These patients were followed up with an average period of 72 weeks to gather prognostic information.

\section{Results}

Nine patients ( 7 females and 2 males) were enrolled with the mean age of disease onset as 59 years old. Three clinical syndromes, including limbic encephalitis $(n=7 ; 78 \%)$, pure amnesia $(n=1 ; 11 \%)$ and fulminant encephalitis $(n=1 ; 11 \%)$ were identified. New symptoms of dysphagia and deafness were identified in the clinical spectrum of anti-AMPAR encephalitis. All patients had positive blood AMPAR antibodies, and six of them (67\%) had paired positive antibodies in cerebrospinal fluid (CSF). Brain magnetic resonance imaging (MRI) were abnormal in 75\% of the patients with no specific patterns recognized. Six patients (67\%) had tumors, including lung cancers or thymomas. After immunotherapy and oncotherapy, partial improvement of neurological symptoms was observed among all 6 patients with available records during their hospitalization. During a mean follow-up of 72 weeks, 3 patients had marked improvement of modified Rankin Scale (mRS), one patient had unchanged mRS, 4 patients died and the other one was lost.

\section{Conclusions}

Anti-AMPAR encephalitis mainly presents as limbic encephalitis. Anti-AMPAR encephalitis is paraneoplastic in $67 \%$ cases and intensive screening for tumors is recommended for all anti-AMPAR patients. Although patients showed a good short-term therapeutic response, the overall prognosis was not satisfactory.

\section{Introduction}

Antibody-mediated encephalitis constitutes a group of inflammatory brain diseases wherein antibodies target directly at cell-surface antigens of neurons and induces varieties of neuropsychiatric disturbances, including behavior changes, psychosis, amnesia, seizures, altered consciousness state and so on[1]. As the understandings of these diseases are deepened and the diagnostic tools matures, the incidence and prevalence of antibody-mediated encephalitis is increasing rapidly, even comparable to infectious encephalitis[2]. However, anti-AMPAR encephalitis is extremely rare. AMPARs are synaptic glutamate-gated cation channels composed of different combinations of four subunits, GluA1 to GluA4, widely expressed in central nervous system. AMPARs mediate fast excitatory synaptic transmission crucial for ongoing fast information processing and synaptic plasticity underling diverse neurophysiological activities, such as learning and memory [3]. In 2009, Meizan Lai et al. first identified antibodies against GluA1/GluA2 of AMPARs in patients with limbic encephalitis, which was often paraneoplastic, responded well to immunological or oncological treatment, and tended to relapse[4]. Since then, no more than 100 cases with diverse clinical manifestations have been reported in literature, posing a great diagnostic challenge due to the clinical heterogeneity and rarity. By reviewing clinical profiles of the 9 patients diagnosed as anti-AMPAR encephalitis, we aim to summarize the clinical patterns and prognosis of the disease, which is helpful for correct diagnosis and prompt treatment.

\section{Material And Methods}

By retrospectively reviewing of patients with positive AMPAR antibodies in CSF or serum, we identified 9 patients finally diagnosed as anti-AMPAR encephalitis between November 2014 and October 2019. Demographic information, clinical symptoms, laboratory studies, which includes CSF analysis, anti-neuronal antibodies in serum or CSF, scalp electroencephalogram (EEG), brain magnetic resonance imaging (MRI), and oncological screenings, treatment and response to treatment were retrieved from the patients' medical records of outpatient visits and hospitalization. Specifically, clinical information of patient No.5, 6 and 9 was obtained by referring physicians and that of rest patients was collected by physicians of our hospitals. Prognosis information was gathered during regular outpatient visits or telephone interviews. Both serum and CSF samples of all patients were sent for antibodies against neuronal cell surface antigens in our hospital. It was decided by both patients and doctors whether or not studies of antibodies against onco-neuronal antigens, brain MRI, EEG and other tests were performed. Written informed consents were obtained from all patients and next of kin/legally authorized representatives of the dead participants. This study was approved by the Research Ethics Committee of Peking Union Medical College Hospital.

Screening for antineuronal antibodies. Anti-neuronal antibodies targeting both cell-surface and intracellular antigens, including N-methyl-D-aspartate receptor (NMDAR), contactin-associated protein-like 2 (CASPR2), AMPA1-R, AMPA2-R, leucine-rich glioma inactivated protein 1 (LGI1), $\gamma$-aminobutyric acid-B receptor (GABAB-R), glutamic acid decarboxylase 65-kilodalton isoform (GAD65), CV2/collapsin response mediator protein 5 (CRMP5), paraneoplastic Ma family (PNMA) 2, Ri, Hu, Yo, and amphiphysin, were tested by cell-based assays (CBA). All serum and cerebrospinal fluid (CSF) antibodies were measured using indirect immunofluorescence test kits purchased from EUROIMMUN AG (Lübeck, Germany) and used according to the manufacturer's instructions. 


\section{Results}

\subsection{Patients and demographic information}

We identified 9 patients with positive AMPAR antibodies in either serum or both CSF and serum from 2014 to 2019 in our hospital. Alternative diagnosis was reasonably excluded. Clinical information, including demographics, clinical presentations, laboratory findings and comorbidities was listed in detail in Table 1. Seven out of the 9 patients (78\%) were female with the rest two male. The mean age of disease onset was 59 years with a range of 50-76 years. The mean time from symptom onset to diagnosis was 18 weeks (range 3-57 weeks). The average modified Rankin Scale (mRS) during initial visit was 4 (range 1-5) (Table 2). 
Table 1

Clinical presentation in patients with anti-AMPAR encephalitis

\begin{tabular}{|c|c|c|c|c|c|c|c|c|c|c|}
\hline $\begin{array}{l}\text { Case } \\
\text { Number }\end{array}$ & Age(years)/sex & $\begin{array}{l}\text { Onset to } \\
\text { Diagnosis } \\
\text { (weeks) }\end{array}$ & $\begin{array}{l}\text { Onset } \\
\text { mode }\end{array}$ & $\begin{array}{l}\text { Initial } \\
\text { symptoms }\end{array}$ & $\begin{array}{l}\text { Other } \\
\text { symptoms } \\
\text { presented } \\
\text { during disease } \\
\text { course }\end{array}$ & MRI & EEG & CSF & $\begin{array}{l}\text { AMPAR } \\
\text { antibodies } \\
\text { (sample } \\
\text { type and } \\
\text { titer) }\end{array}$ & $\begin{array}{l}\text { Other } \\
\text { antiboc }\end{array}$ \\
\hline 1 & $68 / F$ & 57 & Subacute & $\begin{array}{l}\text { Psychiatric } \\
\text { disturbances }\end{array}$ & $\begin{array}{l}\text { Confusion, } \\
\text { amnesia, } \\
\text { ataxia, } \\
\text { dysarthria, and } \\
\text { urinary } \\
\text { incontinence }\end{array}$ & $\begin{array}{l}\text { Increased } \\
\text { signal in right } \\
\text { basal ganglia }\end{array}$ & $\begin{array}{l}\text { Diffuse } \\
\text { low } \\
\text { amplitude } \\
\text { beta wave } \\
\text { activity }\end{array}$ & $\begin{array}{l}\text { Normal } \\
\text { WBC, } \\
55 \mathrm{mg} / \mathrm{dL} \\
\text { protein }\end{array}$ & $\begin{array}{l}\text { CSF 1:32; } \\
\text { blood } \\
1: 32\end{array}$ & $\begin{array}{l}\text { Blood r } \\
(+)\end{array}$ \\
\hline 2 & $52 / M$ & 32 & Acute & Amnesia & $\begin{array}{l}\text { Confusion, } \\
\text { psychiatric } \\
\text { disturbances }\end{array}$ & $\begin{array}{l}\text { Increased } \\
\text { signal in } \\
\text { bilateral } \\
\text { frontal } \\
\text { subcortex }\end{array}$ & NA & $\begin{array}{l}\text { Normal } \\
\text { WBC, } \\
84 \mathrm{mg} / \mathrm{dL} \\
\text { protein }\end{array}$ & $\begin{array}{l}\text { CSF (-); } \\
\text { blood } \\
1: 10\end{array}$ & $(-)$ \\
\hline 3 & $51 / F$ & 20 & Chronic & Amnesia & $\begin{array}{l}\text { Sleep } \\
\text { disorders; } \\
\text { dizziness; right } \\
\text { leg numbness } \\
\text { and paresis }\end{array}$ & $\begin{array}{l}\text { Increased } \\
\text { signal in left } \\
\text { medial } \\
\text { frontoparietal } \\
\text { lobe, right } \\
\text { cingulate } \\
\text { cortex, and } \\
\text { bilateral } \\
\text { cerebellar } \\
\text { hemispheres }\end{array}$ & NA & $\begin{array}{l}\text { Normal } \\
\text { WBC, } \\
66 \mathrm{mg} / \mathrm{dL} \\
\text { protein }\end{array}$ & $\begin{array}{l}\text { CSF 1:10; } \\
\text { blood } \\
1: 32\end{array}$ & $(-)$ \\
\hline 4 & $76 / F$ & 3 & Acute & $\begin{array}{l}\text { Psychiatric } \\
\text { disturbances } \\
\text { and } \\
\text { amnesia }\end{array}$ & - & Normal & Normal & $\begin{array}{l}\text { WBC 15, } \\
\text { normal } \\
\text { protein }\end{array}$ & $\begin{array}{l}\text { CSF (-); } \\
\text { blood } \\
1: 10\end{array}$ & $(-)$ \\
\hline 5 & $64 / F$ & 11 & Chronic & $\begin{array}{l}\text { Psychiatric } \\
\text { disturbances } \\
\text { and } \\
\text { amnesia }\end{array}$ & Confusion & NA & NA & NA & $\begin{array}{l}\text { CSF (-); } \\
\text { blood } \\
1: 100\end{array}$ & NA \\
\hline 6 & $50 / F$ & NA & Subacute & $\begin{array}{l}\text { Psychiatric } \\
\text { disturbances } \\
\text { and } \\
\text { amnesia }\end{array}$ & $\begin{array}{l}\text { Confusion, } \\
\text { intermittent } \\
\text { fever }\end{array}$ & Normal & Normal & $\begin{array}{l}\text { Normal } \\
\text { WBC, } \\
\text { normal } \\
\text { protein }\end{array}$ & $\begin{array}{l}\text { CSF (+); } \\
\text { blood (+), } \\
\text { both titers } \\
\text { unknown }\end{array}$ & NA \\
\hline 7 & $59 / F$ & 12 & Subacute & Amnesia & $\begin{array}{l}\text { Confusion, } \\
\text { altered level of } \\
\text { consciousness, } \\
\text { psychiatric } \\
\text { disturbances, } \\
\text { involuntary } \\
\text { movement, } \\
\text { dizziness and } \\
\text { right face and } \\
\text { perioral } \\
\text { numbness; }\end{array}$ & $\begin{array}{l}\text { Increased } \\
\text { signal in left } \\
\text { frontal lobe, } \\
\text { left parietal } \\
\text { lobe and } \\
\text { right } \\
\text { temporal } \\
\text { lobe }\end{array}$ & $\begin{array}{l}\text { Diffuse } \\
\text { abnormal } \\
\text { (low } \\
\text { amplitude } \\
\text { and } \\
\text { decreased } \\
\text { slow } \\
\text { wave } \\
\text { activities) }\end{array}$ & $\begin{array}{l}\text { Normal } \\
\text { WBC, } \\
58 \mathrm{mg} / \mathrm{dL} \\
\text { protein }\end{array}$ & $\begin{array}{l}\text { CSF } \\
1: 100 ; \\
\text { blood } \\
1: 100\end{array}$ & NA \\
\hline 8 & $63 / \mathrm{M}$ & 5 & Chronic & $\begin{array}{l}\text { Amnesia, } \\
\text { psychiatric } \\
\text { disturbances } \\
\text { and ataxia }\end{array}$ & $\begin{array}{l}\text { Confusion, } \\
\text { sleep disorders, } \\
\text { bilateral } \\
\text { deafness and } \\
\text { dysphagia }\end{array}$ & $\begin{array}{l}\text { Increased } \\
\text { signal in } \\
\text { medial } \\
\text { temporal } \\
\text { lobes }\end{array}$ & $\begin{array}{l}\text { Slightly } \\
\text { increased } \\
\text { theta } \\
\text { activity }\end{array}$ & $\begin{array}{l}\text { Normal } \\
\text { WBC, } \\
86 \mathrm{mg} / \mathrm{dL} \\
\text { protein }\end{array}$ & $\begin{array}{l}\text { CSF 1:10; } \\
\text { blood } \\
1: 100\end{array}$ & $(-)$ \\
\hline 9 & $51 / F$ & 3 & Acute & $\begin{array}{l}\text { psychiatric } \\
\text { disturbances }\end{array}$ & $\begin{array}{l}\text { Confusion, } \\
\text { fever, apathy, } \\
\text { dysarthria, } \\
\text { dysphagia, } \\
\text { arrythmia, } \\
\text { difficulty in } \\
\text { defecation and } \\
\text { urination, } \\
\text { central } \\
\text { hypoventilation }\end{array}$ & $\begin{array}{l}\text { Diffuse } \\
\text { increased } \\
\text { signal in } \\
\text { bilateral } \\
\text { cortex and } \\
\text { subcortex }\end{array}$ & NA & $\begin{array}{l}\text { Normal } \\
\text { WBC, } \\
\text { normal } \\
\text { protein }\end{array}$ & $\begin{array}{l}\text { CSF (+); } \\
\text { blood (+), } \\
\text { both titers } \\
\text { unknown }\end{array}$ & $\begin{array}{l}\text { Blood r } \\
(+)\end{array}$ \\
\hline
\end{tabular}


Table 2

Summarization of clinical profiles of patients with anti-AMPAR encephalitis

\begin{tabular}{|c|c|c|c|}
\hline Demographics & Range & Mean & NA (\%) \\
\hline Sex & & $2 \mathrm{M} / 7 \mathrm{~F}$ & 0 \\
\hline Age (years) & $50-76$ & 59 & 0 \\
\hline mRS (initial) & $1-5$ & 4 & 0 \\
\hline mRS (last follow-up) & $0-6$ & 5 & $2(22)$ \\
\hline Onset to diagnosis (weeks) & $3-57$ & 18 & $1(11)$ \\
\hline Clinical symptoms & $\mathbf{N}$ & positive & NA (\%) \\
\hline Acute onset & 3 & $33 \%$ & 0 \\
\hline Subacute onset & 3 & $33 \%$ & 0 \\
\hline Chronic onset & 3 & $33 \%$ & 0 \\
\hline Amnesia & 8 & $89 \%$ & 0 \\
\hline Psychosis & 8 & $89 \%$ & 0 \\
\hline Ataxia & 2 & $22 \%$ & 0 \\
\hline Fever & 2 & $22 \%$ & 0 \\
\hline Sleep disorders & 2 & $22 \%$ & 0 \\
\hline Dysautonomia & 2 & $22 \%$ & 0 \\
\hline Numbness & 2 & $22 \%$ & 0 \\
\hline Dysarthria & 2 & $22 \%$ & 0 \\
\hline Dysphagia & 2 & $22 \%$ & 0 \\
\hline Deafness & 1 & $11 \%$ & 0 \\
\hline Altered levels of consciousness & 1 & $11 \%$ & 0 \\
\hline Involuntary movement & 1 & $11 \%$ & 0 \\
\hline Seizures & 0 & $0 \%$ & 0 \\
\hline Laboratory and MRI findings & $\mathbf{N}$ & Positive & NA (\%) \\
\hline Only Blood AMPAR Ab (+) & 3 & $33 \%$ & 0 \\
\hline Only CSF AMPAR Ab (+) & 0 & $0 \%$ & 0 \\
\hline Blood and CSF AMPAR Ab (+) & 6 & $67 \%$ & 0 \\
\hline Other Onco-neuronal Abs & 2 & $33 \%$ & $3(33)$ \\
\hline Increased CSF protein & 5 & $63 \%$ & $1(11)$ \\
\hline Increased CSF WBC & 1 & $13 \%$ & $1(11)$ \\
\hline MRI abnormal & 6 & $75 \%$ & $1(11)$ \\
\hline EEG abnormal & 3 & $60 \%$ & $4(44)$ \\
\hline Tumor identified & 6 & $67 \%$ & 0 \\
\hline
\end{tabular}

\subsection{Clinical Presentations And Mri/eeg Findings}

Onset modes of the disease were acute in 3 patients, subacute in 3 patients and chronic in 3 patients. The spectrum of disease presentation was broad with most prominent symptoms as psychiatric disturbances (8 patients), confusion (8 patients), and amnesia (8 patients). We also identified symptoms such as fever (2 patients), paresthesia ( 2 patients), dysarthria (2 patients), dysphagia (2 patients), sleep disorders (2 patients), ataxia (2 patients), dysautonomia (2 patients), altered level of consciousness (1 patient), involuntary movement (1 patient), deafness (1 patient) and so on during course of the disease. Among the 8 patients with brain MRI available, $6(75 \%)$ had abnormal MRI findings, that is, T2/T2 fluid-attenuated inversion recovery (FLAIR) hyperintensities, which were not restricted to the limbic system, but also involved structures like cortex and subcortex, basal ganglia, and cerebellum.

Three major clinical modes of anti-AMPAR encephalitis were identified according to the type of disease onset and prominent clinical symptoms. Seven patients manifested as limbic encephalitis (LE), defined as presence of at least two of the following symptoms, confusion, amnesia, and psychosis developed 
acutely or subacutely. One patient had pure amnesia and the remaining one had fulminant encephalitis.

The onset modes of patients with limbic encephalitis varied from acute (2 patients), subacute (3 patients) to chronic ( 2 patients). In addition to the typical LE symptoms, rare symptoms accompanied, such as ataxia, urinary incontinence, sleep disorders, dysphagia, dysarthria, dizziness, deafness, and involuntary movement. Interestingly, none of the patients showed typical limbic lesions in MRI. Two (patient No. 4, 6) had normal MRI and the rest ones had increased T2/FLAIR signals in basal ganglia and frontal, temporal, and parietal lobes. The two patients with normal MRI also had normal EEG. For patients No. 1, 7, 8 , who had available EEG data, the appearance of EEG was unspecific decreased frequency or amplitude of brain waves, with no epileptic activity recorded.

For the patient with isolated amnesia at initial presentation (No.3), who was a 51-year-old female, the course of disease was chronic. She gradually developed retrograde amnesia, insomnia, right leg numbness and paresis in 10 months. Electromyography indicated right-side neurogenic impairment at L5-S1 level. The brain MRI demonstrated increased signal in left medial frontoparietal lobe, right insular cortex, and bilateral cerebella hemispheres (figure 1), which extended beyond the limbic system and didn't match her symptoms perfectly. The patient didn't have psychosis and ataxia as anticipated.

The patient No. 9 was a 51-year-old female, who had a fulminant disease course and purely psychiatric symptoms without significant memory loss. Her symptoms were acutely onset during the treatment of liver fluke, and later within one week she quickly developed fever with a maximal temperature of $39.0{ }^{\circ} \mathrm{C}$, confusion, apathy, sialorrhea, dysarthria, difficulty in defecation and urination, arrythmia and central hypoventilation. She was admitted into ICU and required ventilator for respiratory assistance. The brain MRI showed diffuse bilateral abnormal signal in both cortex and subcortex areas, which was in consistent with her symptoms.

\subsection{Laboratory Findings}

All patients except one (patient No.5) underwent lumber puncture and the CSF samples were sent for routine and biochemical tests. Five (63\%) had elevated CSF protein ranging from $55 \mathrm{mg} / \mathrm{dL}$ to $88 \mathrm{mg} / \mathrm{dL}$, while only one (13\%) had elevated leukocytes of $15 / \mathrm{mm}^{3}$.

All patients' sera and CSF were tested for anti-neuronal antibodies as discussed above. All patients had positive blood AMPAR antibodies, and six of them had paired positive antibodies in CSF. Titers type ranged from 1:10 to 1:100 in both sample types. None of our patients tested positive for AMPAR antibodies only in CSF samples. Although we tested antibodies for both GluA1 subunit and GluA2 subunit, only antibodies against GluA2 subunit of AMPAR were positive. In 6 patients who tested for onco-neuronal antibodies, only patient No.1 and patient No.9 had positive Hu antibody in blood samples. Although Hu antibody was tumor-associated, only patient No.9 had thymoma and no tumor was found in patient No.1 despite of intensive tumor screenings.

\subsection{Tumor State}

Intensive tumor screenings including tumor marker panels, whole body CT, PET-CT, and specific diagnostic tools for suspected tumors, such as mammography, and gastrointestinal endoscopy, were selectively applied in all nine patients. Six (67\%) patients were found to have tumors, four of which were pathologically confirmed with the rest two indicated by radiology. Two patients had lung cancers. One (patient No.3) had small cell lung cancer confirmed by tracheoscope-guided transbronchial lung biopsy and the other (patient No.9) had radiologically irregular soft-tissue mass in the anterior basal segment of the right lower lung lobe with multiple enlarged lymph nodes at right hilum and mediastinum, suggestive of malignant lung tumor. However, due to age and economic concerns, the patient and her families refused further assessment. Four patients had thymomas, three of which were confirmed by surgical pathology and one of which was radiologically suspected. In patient No. 6 and No. 7, the pathological type of thymoma were type B3, while that of patient No. 5 were unavailable. Due to limited patient number, no obvious correlation between tumor state and demographic factors, clinical presentations or prognosis was observed.

\subsection{Treatment And Follow Up}

Six patients received first-line immunotherapy, including intravenous immunoglobulin (IVIG), steroids and plasmapheresis (Table 3). The IVIG treatments were applied in standard dosage as $2.0 \mathrm{~g} / \mathrm{kg}$ with the exception of patient No.8, who had two rounds of IVIG treatment. Steroid treatments were administered in one to three pulses followed by maintenance dosage. Patient No.3 and patient No.8 received second-line immunomodulators, mycophenolate mofetil (MMF) and azathioprine (Aza), respectively. The rest three patients did not accept any immunotherapy. Patient No.2 received only symptomatic treatment for psychiatric disturbances and mood disorders. For the six patients with identified or suspected tumors, patient No.5 received surgical resection, and patient No.6 and No.7 received surgical resection and radiotherapy, according to the pathological type of tumors and the oncologists' suggestions. The initial treatment response during hospitalization was all active for patients who received treatment in our hospital (patient No. 1-4, 7 and 8 ) despite of tumor state and therapy type, and that of the other three was not available.

During the follow-up period ranging from 2 to 214 weeks, 3 patients (patient No. 1, 3, 7) had marked improvement of mRS, one (patient No.4) had unchanged mRS, 4 died (patient No.2, 5, 8, 9) and the other one (patient No.6) was lost, as shown in Table 3. Marked improvement of mRS was defined as decrease of at least 2 scores with an $\mathrm{mRS}$ at last follow-up $\leq 3$. There seemed no significant survival difference between patients with and without tumors. Three out of the five patients with tumors died at last, in which patient No. 2 and No.8 died of tumors, and patient No.9 died of subsequent multiple organ dysfunction syndrome comorbid with her fulminant encephalitis. One patient (No.8) of the three without tumors died because of aspirational pneumonia. 
Table 3

Treatment and prognosis of patients with anti-AMPAR encephalitis

\begin{tabular}{|c|c|c|c|c|c|}
\hline $\begin{array}{l}\text { Case } \\
\text { Number }\end{array}$ & Treatment & Short-term treatment response & $\begin{array}{l}\mathrm{mRS} \\
\text { initial }\end{array}$ & $\begin{array}{l}\mathrm{mRS} \text { at last } \\
\text { follow-up }\end{array}$ & $\begin{array}{l}\text { follow-up } \\
\text { (weeks) }\end{array}$ \\
\hline 1 & IVIG, steroids & $\begin{array}{l}\text { Significant improvement in cognition, psychosis and ataxia; } \\
\text { urinary incontinence disappears }\end{array}$ & 5 & 3 & 28 \\
\hline 2 & Symptomatic & Improvement in mood disorders and psychosis & 3 & 6 & 23 \\
\hline 3 & $\begin{array}{l}\text { IVIG, plasmapheresis, steroids, } \\
\text { MMF }\end{array}$ & Numbness improved & 4 & 2 & 75 \\
\hline 4 & IVIG, steroids & Improvement in amnesia & 3 & 3 & 131 \\
\hline 5 & Tumor resection & NA & 3 & 6 & 2 \\
\hline 6 & $\begin{array}{l}\text { Tumor resection + } \\
\text { radiotherapy }\end{array}$ & NA & NA & NA & NA \\
\hline 7 & $\begin{array}{l}\text { Tumor resection }+ \\
\text { radiotherapy, IVIG, steroids }\end{array}$ & Significant improvement in consciousness level and psychosis & 5 & 0 & 214 \\
\hline 8 & IVIG, steroids, Aza & Improvement in psychosis & 3 & 6 & 74 \\
\hline 9 & IVIG, steroids & NA & 5 & 6 & 30 \\
\hline
\end{tabular}

No clinical relapse was observed in our patients. It's noteworthy that patient No.7 with malignant thymoma and subsequent tumor therapy was later diagnosed as myasthenia gravis. After receiving formal and regular immunotherapy, she remained asymptomatic.

\section{Discussion}

In this article, we identified 9 anti-AMPAR encephalitis patients in our hospital and summarized their clinical characteristics. The patients were generally middle-aged elderly women with a median onset age of 59 years old and a female-to-male ratio of 3.5: 1. Onset modes of the symptoms varied from acute, subacute to chronic. Three clinical modes including limbic encephalitis, pure amnesia and fulminant encephalitis were identified with LE the majority. Brain MRI were abnormal in $75 \%$ of the patients with no specific patterns recognized. All patients have positive blood AMPAR antibodies, and $67 \%$ of them have paired antibodies in CSF. Sixty-seven percent patients had tumors, lung cancers or thymomas. After immunotherapy and onco-therapy, partial improvement of neurological symptoms was observed among all 6 patients with available records during their hospitalization. During follow-up, 3 patients had marked improvement of $\mathrm{mRS}$, one patient had unchanged $\mathrm{mRS}, 4$ patients died and the other one was lost.

The demographic characteristics of anti-AMPAR encephalitis revealed by this research were similar to that of other studies [4-7]. In the original study that identified AMPAR as a novel antigen in 10 limbic encephalitis patients, the median age was 60 and 9 of the 10 patients were female, while in the recent systemic review covering 55 cases of anti-AMPAR encephalitis, the median age was 53.2 years old with a range of 14 to 92 and the female-to-male ratio was 36 to $19[4,7]$.

Anti-AMPAR encephalitis was initially recognized as limbic encephalitis, and later research identified more clinical patterns[4]. Hoftberger et al summarized four clinical modes in 22 patients, including limbic encephalitis (12 patients), diffuse encephalitis (8 patients), limbic encephalitis preceded by motor deficits (1 patient) and pure psychosis (1 patient) [5]. Joubert et al identified four main modes according to the prominent onset symptoms in a seven-patients cohort, including confusion (3 patients), isolated epileptic (1 patient), isolated amnestic (1 patient) and fulminant encephalitis (2 patients) [6]. Our study yielded similar results with 7 patients as LE, 1 purely amnestic and 1 fulminant encephalitis. However, the clinical presentations were highly variable, ranging from the commonly seen symptoms of limbic encephalitis as psychosis, confusion, and amnesia, to the infrequent symptoms of seizure, dysautonomia, ataxia or other cerebellar symptoms, insomnia, involuntary movements, dysarthria, sensory symptoms and so on. We expanded the clinical spectrum of anti-AMPAR encephalitis by adding dysphagia and deafness. The bilateral deafness developed as a prominent symptom during the disease course without prior identifiable risks, such as ototoxic drugs and so on. This manifestation was also observed in a recently diagnosed patient, which is not included in this series. The expanding profiles will help clinicians better recognize patients with atypical presentations, and reduce the rate of misdiagnosis and missed diagnosis.

Despite the diverse symptoms mentioned above in anti-AMPAR encephalitis, limbic encephalitis remains the majority. Additionally, clinicians should always meticulously rule out anti-AMPAR encephalitis in patients with pure amnesia or psychosis, as the disease is treatable and may be comorbid with tumors.

Limbic encephalitis is frequently seen in autoimmune encephalitis, such as anti-NMDAR, GABAB-R, CASPR2, LGI1 and AMPAR encephalitis, suggesting common mechanisms underlined. Limbic encephalitis in anti-AMPAR encephalitis is thought to be caused by antibody-mediated internalization of AMPAR clusters at synapses[4]. Increased availability of AMPAR clusters is critical for long-term potentiation in the hippocampus therefore for memory consolidation [8]. Specifically, GluA2 antibodies resulted in reduction of synaptic GluA2-containing AMPARs, impairment of long-term synaptic plasticity in vitro, and damaged learning and memory in vivo[9].This explains amnesia in anti-AMPAR encephalitis patients and provides insights into the symptomatic overlap with LGI1 encephalitis, as LGI1-ADAM22 complex interacting with PSD95 stabilizes AMPARs in the postsynaptic membrane[10, 11]. The glutamate hypothesis of psychosis indicates that hypofunction of GABAergic neurons may account for psychiatric symptoms in some autoimmune encephalitis. Indeed, internalization of NMDARs by GluN1 antibodies and AMPARs by GluA1/GluA2 antibodies affects the activities of cortical networks[3, 12]. Epilepsy is commonly encountered in autoimmune encephalitis. One proposed mechanism is that increased seizure susceptibility is due to reduced inhibitory neurotransmission as indicated in GABAA-R, GABAB-R and GAD65 encephalitis[13-16]. In hippocampal pyramidal neurons treated with CSF of anti-AMPAR 
encephalitis patients, patch-clamp revealed decreased miniature excitatory postsynaptic currents (EPSCs), which seemed paradoxical to seizures in patients[17]. Explanation was that decreased EPSCs resulted in decreased inhibitory synaptic transmission and increased the intrinsic excitability, predisposing patients to epilepsy[17]. However, seizures were relatively rarely observed in anti-AMPAR encephalitis as in other autoimmune encephalitis mentioned above. The discrepancy of seizure incidence and type in different antibody-mediated encephalitis remains unexplained.

Brain MRI, EEG, CSF study and antibody test are the main diagnostic tools for anti-AMPAR encephalitis. Brain MRI is considered as a sensitive but not specific diagnostic tool for anti-AMPAR encephalitis. According to the systemic review including the largest patient number of 55 , up to $86 \%$ of the patients had abnormal brain MRI with a predilection for bilateral temporal lobes, which was related to topography of GluA1 and GluA2 expression [7]. Seventy-five percent of our patients had abnormal brain MRI, with no preference for specific brain sites. However, it should be noted that patients of anti-AMPAR encephalitis may have completely normal brain MRI as indicated by our patients and the imaging abnormalities may spread to locations unexpected, like basal ganglia, cerebellum, and even posterior temporal and parieto-occipital regions[18]. Therefore, for patients with nonspecific MRI manifestations but with typical symptoms, anti-AMPAR encephalitis should be cautiously differentiated. EEG was less sensitive than brain MRI and only $44 \%$ patients had EEG abnormalities [7]. EEG was also unspecific, varying from nonspecific slowing, epileptiform activities to normal. The most common EEG abnormality in our patients were nonspecific slowing. Cerebrospinal fluid study has limited significance for differential diagnosis. Systemic analysis revealed that inflammatory CSF changes, defined as pleocytosis, increased CSF protein levels, and/or oligoclonal band, were rather frequent seen in NMDAR, GABABR, AMPAR, and dipeptidyl-peptidaselike protein 6 (DPPX) encephalitis while in autoimmune encephalitis with either CASPR2, LGI1, GABAA, or glycine receptor antibodies, CSF findings were generally normal[19]. In accordance with this systemic review, five patients (63\%) in our study had elevated CSF protein and one (13\%) patient showed pleocytosis in CSF. Blood and CSF AMPAR antibodies were the definitive diagnostic markers for anti-AMPAR encephalitis. Different from other studies, our study showed that the positivity rate of AMPAR antibodies were higher in serum than in CSF and that only GluA2 antibodies were detected. The difference might be accounted by the relatively small number of patients included. These findings suggest that for patients suspicious of anti-AMPAR encephalitis, both serum and CSF should be sent for antibody tests. Interestingly, the difference of clinical profiles between patients with antibodies against GluA1 and GluA2 was not clear yet, awaiting further investigation.

Anti-AMPAR encephalitis may present as paraneoplastic encephalitis related to systemic tumor. Forty-eight to seventy percent patients were found to have tumors, mostly lung, thymus, breast, and ovarian tumors[4-7]. Six patients $(67 \%)$ in our study had tumors, three of which had lung cancers and the rest thymomas. Additionally, rare tumors including medullary thyroid cancer, malignant melanoma and Ewing's Sarcoma were also reported in anti-AMPAR encephalitis cases[20-22]. Psychiatric symptoms at presentation predicted the presence of tumors [7]. These findings suggest that in anti-AMPAR encephalitis patients, extensive tumor screening is necessary, especially for those with psychiatric symptoms. In addition to tumors, patients of anti-AMPAR encephalitis seem to have a predisposition to other autoimmune diseases. Systemic lupus erythematous, Hashimoto's thyroiditis, and myasthenia gravis were reported to be concurrent with anti-AMPAR encephalitis[23-25]. Therefore, signs of autoimmune diseases should also be paid attention to when anti-AMPAR encephalitis is suspected.

Treatment of anti-AMPAR encephalitis includes immunotherapy and oncological treatment if tumors are comorbid. Immunotherapy is composed of first-line therapies, such as IVIG, steroids and plasmapheresis, and second-line therapies, such as rituximab and immunosuppressants. Treatment response, defined as $\mathrm{mRS}$ decrease with an $\mathrm{mRS} \leq 3$ at the last follow-up, was observed in $71 \%$ of the patients reported in literature and in 3 of 8 patients in our cohort[5]. The overall survival rate of patients with and without tumors was not significantly different as indicated by our study and literature[5]. The poor prognosis is unlikely related to delayed diagnosis and treatment, as indicated by the three patients who died despite of prompt diagnosis and adequate treatment. The presence of psychiatric symptoms and concurrent onco-neuronal antibodies were associated with poorer outcomes while younger age and confusion at presentation was linked with favorable prognosis[5, 7]. This was also observed in patients of anti-AMPAR encephalitis with concurrent CRMP5 antibodies [26].Fulminant encephalitis was associated with poor prognosis. Whether or not presence of tumors or onco-neuronal antibodies predicts relapse remains elusive. Cases have been reported that anti-AMPAR encephalitis and the comorbid tumor relapsed after immunological and oncological treatments but not in our patients[27]. It seems that patients who received aggressive therapy (chemotherapy and rituximab) was unlikely to have relapses than those who did not[5].Therefore, it's important to closely follow up the patient after treatment.

Taken together, our study characterized a series of anti-AMPAR encephalitis patients from China and expand the clinical features of anti-AMPAR encephalitis. However, the limitations are obvious in terms of case number. Better understandings of this disease, including its symptoms, comorbidities, prognosis and development of better diagnostic and therapeutic maneuvers, rely on deeper investigations into the pathological mechanisms and the accumulation of patient numbers.

\section{Conclusion}

Encephalitis associated with antibodies against AMPAR is an extremely rare type of antibody-mediated encephalitis. Three clinical syndromes, including limbic encephalitis, pure amnesia and fulminant encephalitis were identified, with limbic encephalitis the majority. Anti-AMPAR encephalitis paraneoplastic in $67 \%$ cases and intensive screening for tumors is recommended for all anti-AMPAR patients. Although all patients showed a good short-term therapeutic response, the overall prognosis was not satisfactory.

\section{Abbreviations}

AMPAR: alpha-amino-3-hydroxy-5-methyl-4-isoxazolepropionic acid receptor

Aza: azathioprine

CASPR2: contactin-associated protein-like 2 
CBA: cell-based assay

CRMP5: collapsin response mediator protein 5

CSF: cerebrospinal fluid

DPPX: dipeptidyl-peptidase-like protein 6

EEG: electroencephalogram

FLAIR: fluid-attenuated inversion recovery

GABAB-R: $y$-aminobutyric acid-B receptor

GAD65: glutamic acid decarboxylase 65-kilodalton isoform

IVIG: intravenous immunoglobulin

LE: limbic encephalitis

LGI1: leucine-rich glioma inactivated protein 1

MMF: mycophenolate mofetil

MRI: magnetic resonance imaging

mRS: modified Rankin Scale

NMDAR: N-methyl-D-aspartate receptor

PNMA: paraneoplastic Ma family

\section{Declarations}

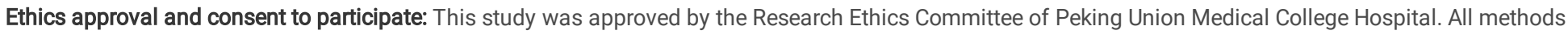
were carried out in accordance with relevant guidelines and regulations.

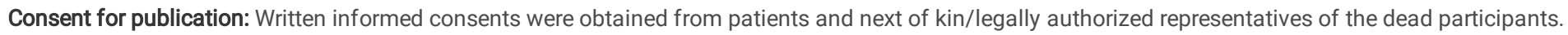

Availability of data and materials: All data used and/or analyzed during the study is available on request from the corresponding author.

Competing interests: The authors declare that they have no competing interests.

Funding: The work was supported by CAMS Innovation Fund for Medical Sciences (CIFMS 2020-I2M-C\&T-B-012).

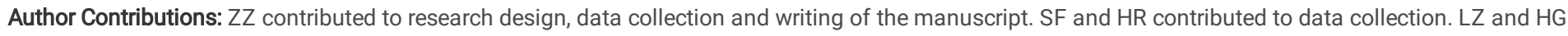
contributed to research design and revision of the manuscript.

Acknowledgements: Not applicable.

\section{References}

1. Dalmau J, Graus F. Antibody-Mediated Encephalitis. N Engl J Med. 2018;378 9:840-51; doi: 10.1056/NEJMra1708712.

2. Dubey D, Pittock SJ, Kelly CR, McKeon A, Lopez-Chiriboga AS, Lennon VA, et al. Autoimmune encephalitis epidemiology and a comparison to infectious encephalitis. Ann Neurol. 2018;83 1:166-77; doi: 10.1002/ana.25131.

3. Diering GH, Huganir RL. The AMPA Receptor Code of Synaptic Plasticity. Neuron. 2018;100 2:314-29; doi: 10.1016/j.neuron.2018.10.018.

4. Lai M, Hughes EG, Peng X, Zhou L, Gleichman AJ, Shu H, et al. AMPA receptor antibodies in limbic encephalitis alter synaptic receptor location. Ann Neurol. 2009;65 4:424-34; doi: 10.1002/ana.21589.

5. Hoftberger R, van Sonderen A, Leypoldt F, Houghton D, Geschwind M, Gelfand J, et al. Encephalitis and AMPA receptor antibodies: Novel findings in a case series of 22 patients. Neurology. 2015;84 24:2403-12; doi: 10.1212/WNL.0000000000001682.

6. Joubert B, Kerschen P, Zekeridou A, Desestret V, Rogemond V, Chaffois MO, et al. Clinical Spectrum of Encephalitis Associated With Antibodies Against the alpha-Amino-3-Hydroxy-5-Methyl-4-Isoxazolepropionic Acid Receptor: Case Series and Review of the Literature. JAMA Neurol. 2015;72 10:1163-9; doi: 10.1001/jamaneurol.2015.1715.

7. Laurido-Soto O, Brier MR, Simon LE, McCullough A, Bucelli RC, Day GS. Patient characteristics and outcome associations in AMPA receptor encephalitis. J Neurol. 2019;266 2:450-60; doi: 10.1007/s00415-018-9153-8. 
8. Petit-Pedrol M, Sell J, Planaguma J, Mannara F, Radosevic M, Haselmann H, et al. LGI1 antibodies alter Kv1.1 and AMPA receptors changing synaptic excitability, plasticity and memory. Brain. 2018;141 11:3144-59; doi: 10.1093/brain/awy253.

9. Haselmann H, Mannara F, Werner C, Planaguma J, Miguez-Cabello F, Schmidl L, et al. Human Autoantibodies against the AMPA Receptor Subunit GluA2 Induce Receptor Reorganization and Memory Dysfunction. Neuron. 2018;100 1:91-105 e9; doi: 10.1016/j.neuron.2018.07.048.

10. Ohkawa T, Fukata Y, Yamasaki M, Miyazaki T, Yokoi N, Takashima H, et al. Autoantibodies to epilepsy-related LGI1 in limbic encephalitis neutralize LGI1ADAM22 interaction and reduce synaptic AMPA receptors. J Neurosci. 2013;33 46:18161-74; doi: 10.1523/JNEUROSCI.3506-13.2013.

11. Lovero KL, Fukata Y, Granger AJ, Fukata M, Nicoll RA. The LGI1-ADAM22 protein complex directs synapse maturation through regulation of PSD-95 function. Proc Natl Acad Sci U S A. 2015;112 30:E4129-37; doi: 10.1073/pnas.1511910112.

12. Masdeu JC, Dalmau J, Berman KF. NMDA Receptor Internalization by Autoantibodies: A Reversible Mechanism Underlying Psychosis? Trends Neurosci. 2016;39 5:300-10; doi: 10.1016/j.tins.2016.02.006.

13. Benarroch EE. AMPA receptors: Dynamics and targets of disease. Neurology. 2016;87 12:1281-8; doi: 10.1212/WNL.0000000000003138.

14. Petit-Pedrol M, Armangue T, Peng X, Bataller L, Cellucci T, Davis R, et al. Encephalitis with refractory seizures, status epilepticus, and antibodies to the GABAA receptor: a case series, characterisation of the antigen, and analysis of the effects of antibodies. Lancet Neurol. 2014;13 3:276-86; doi: 10.1016/S1474-4422(13)70299-0.

15. Spatola M, Dalmau J. Seizures and risk of epilepsy in autoimmune and other inflammatory encephalitis. Curr Opin Neurol. 2017;30 3:345-53; doi: 10.1097/WCO.0000000000000449.

16. Li X, Guo Q, Zheng Z, Wang X, Liu S. Immune-mediated epilepsy with GAD65 antibodies. J Neuroimmunol. 2020;341:577189; doi: 10.1016/j.jneuroim.2020.577189.

17. Peng X, Hughes EG, Moscato EH, Parsons TD, Dalmau J, Balice-Gordon RJ. Cellular plasticity induced by anti-alpha-amino-3-hydroxy-5-methyl-4isoxazolepropionic acid (AMPA) receptor encephalitis antibodies. Ann Neurol. 2015;77 3:381-98; doi: 10.1002/ana.24293.

18. Elamin M, Lonergan R, Killeen RP, O'Riordan S, Tubridy N, McGuigan C. Posterior cortical and white matter changes on MRI in anti-AMPA receptor antibody encephalitis. Neurol Neuroimmunol Neuroinflamm. 2015;2 4:e118; doi: 10.1212/NXI.0000000000000118.

19. Blinder T, Lewerenz J. Cerebrospinal Fluid Findings in Patients With Autoimmune Encephalitis-A Systematic Analysis. Front Neurol. 2019;10:804; doi: 10.3389/fneur.2019.00804.

20. Samad N, Wong J. Anti-AMPA receptor encephalitis associated with Medullary thyroid cancer. BMJ Case Rep. 2018;2018; doi: 10.1136/bcr-2018-225745.

21. Koh D, Lau T, Teoh E, Lau KK. An Uncommon Presentation of a Primary Bone Tumor: Anti-AMPA (Anti-alpha-Amino-3-Hydroxy-5-Methyl-4Isoxazolepropionic acid) Receptor Limbic/Paraneoplastic Encephalitis as a Presenting Feature of Ewing Sarcoma. J Pediatr Hematol Oncol. 2018;40 7:555-7; doi: 10.1097/MPH.0000000000001304.

22. Daneshmand A, Goyal G, Markovic S, Zekeridou A, Wijdicks EFM, Hocker SE. Autoimmune Encephalitis Secondary to Melanoma. Ann Intern Med. 2019;170 12:905-6; doi: 10.7326/L18-0593.

23. Zaeem Z, Luk CC, Anderson D, Blevins G, Siddiqi ZA. AMPA-R Limbic Encephalitis Associated with Systemic Lupus Erythematosus. Can J Neurol Sci. 2020:1-2; doi: 10.1017/cjn.2020.70.

24. Zhu M, Yu X, Liu C, Duan C, Li C, Zhu J, et al. Hashimoto's encephalitis associated with AMPAR2 antibodies: a case report. BMC Neurol. 2017;17 1:37; doi: 10.1186/s12883-017-0823-4.

25. Li X, Mao YT, Wu JJ, Li LX, Chen XJ. Anti-AMPA receptor encephalitis associated with thymomatous myasthenia gravis. J Neuroimmunol. 2015;281:35-7; doi: 10.1016/j.jneuroim.2015.02.011.

26. Jia Y, Wang J, Xue L, Hou Y. Limbic encephalitis associated with AMPA receptor and CRMP5 antibodies: A case report and literature review. Brain Behav. 2020;10 3:e01528; doi: 10.1002/brb3.1528.

27. Omi T, Kinoshita M, Nishikawa A, Tomioka T, Ohmori K, Fukada K, et al. Clinical Relapse of Anti-AMPAR Encephalitis Associated with Recurrence of Thymoma. Intern Med. 2018;57 7:1011-3; doi: 10.2169/internalmedicine.9682-17.

\section{Figures}



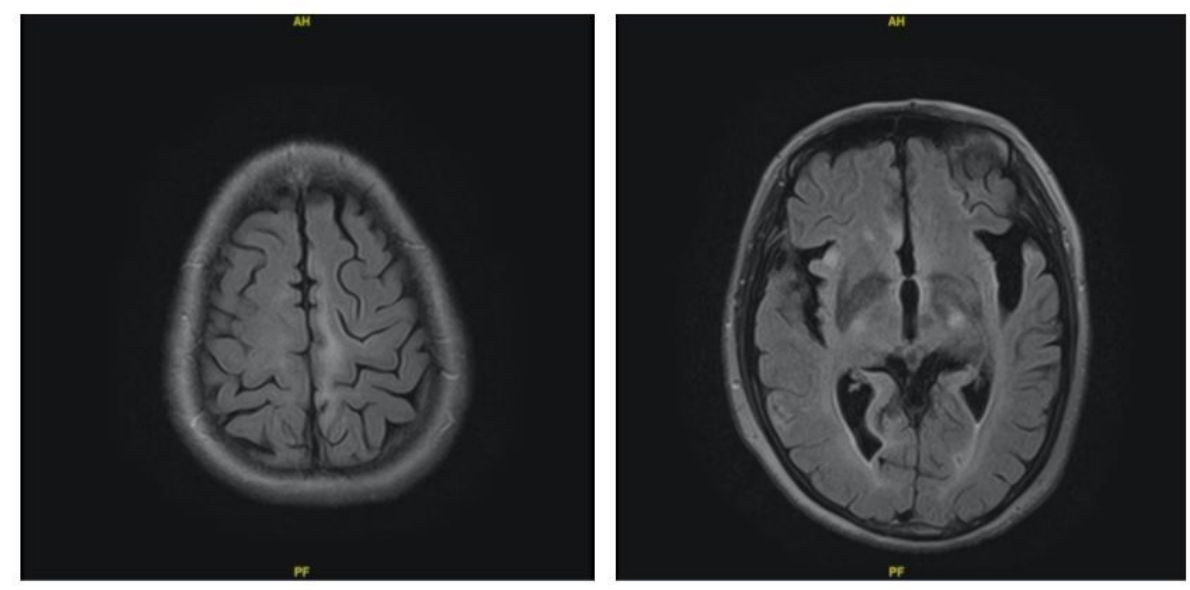

A

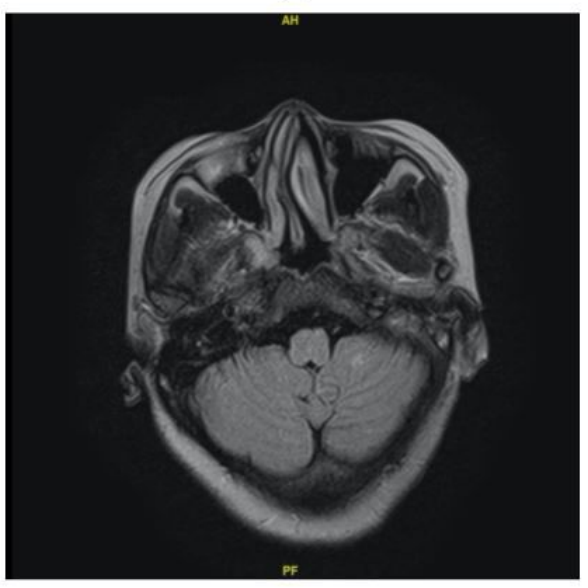

B

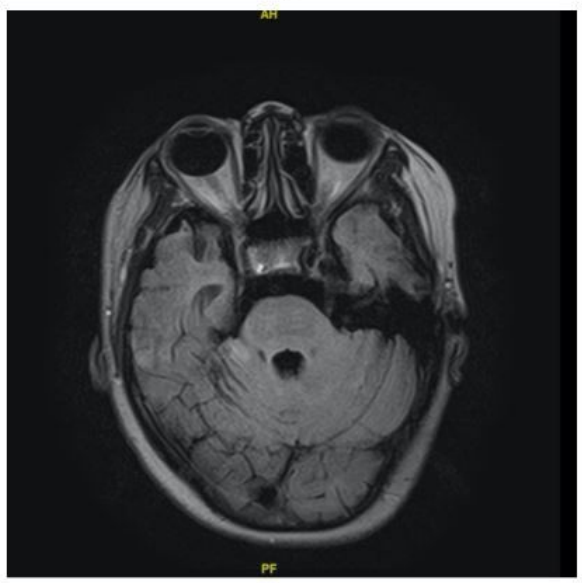

C

D

\section{Figure 1}

Brain MRI findings of patient No.3. The brain MRI was obtained when the patient was admitted and 10 months after symptom onset, showing that increased fluid-attenuated inversion recovery (FLAIR) signal in left medial frontoparietal lobe (A), right insular cortex (B), and bilateral cerebellar hemispheres (C, D). The signal abnormalities extend beyond the limbic system. 